\title{
Lupe Cotrim: algumas lições do amigo
}

\author{
Leila V.B. Gouvêa ${ }^{1}$
}

Resumo

A partir do estudo da correspondência inédita entre Lupe Cotrim Garaude e Carlos Drummond de Andrade, este artigo propõe uma revisita à trajetória literária, intelectual e humana da escritora paulista, falecida em 1970, cujo acervo foi recentemente incorporado ao conjunto de fundos pessoais do Instituto de Estudos Brasileiros da Universidade de São Paulo (IEB-USP).

\section{Palavras-chave}

Lupe Cotrim Garaude, Carlos Drummond de Andrade, poesia lírica, cartas, "geração $60 "$.

1 Doutora em Literatura Brasileira pela Faculdade de Filosofia, Letras e Ciências Humanas da Universidade de São Paulo (FFLCH/USP), desenvolve pesquisa de pósdoutorado no IEB sob supervisão da Profa. Dra. Yêdda Dias Lima, com bolsa da Fundação de Amparo à Pesquisa do Estado de São Paulo (Fapesp), sobre obra e vida da poeta Lupe Cotrim Garaude. São Paulo, Brasil. e-mail: leila.gouvea@gmail.com 


\section{Lupe Cotrim Garaude: some friend's lessons}

Leila V.B. Gouvêa

\section{Abstract}

Dealing with the unpublished correspondence between Lupe Cotrim Garaude and Carlos Drummond de Andrade, this article intends to revisit the literary, intellectual and human path of the São Paulo writer, whose private records have recently been incorporated into the Archives of the Instituto de Estudos Brasileiros of the Universidade de São Paulo (IEB-USP).

Keywords

Lupe Cotrim Garaude, Carlos Drummond de Andrade, lyric poetry, letters, "the 60 s generation". 


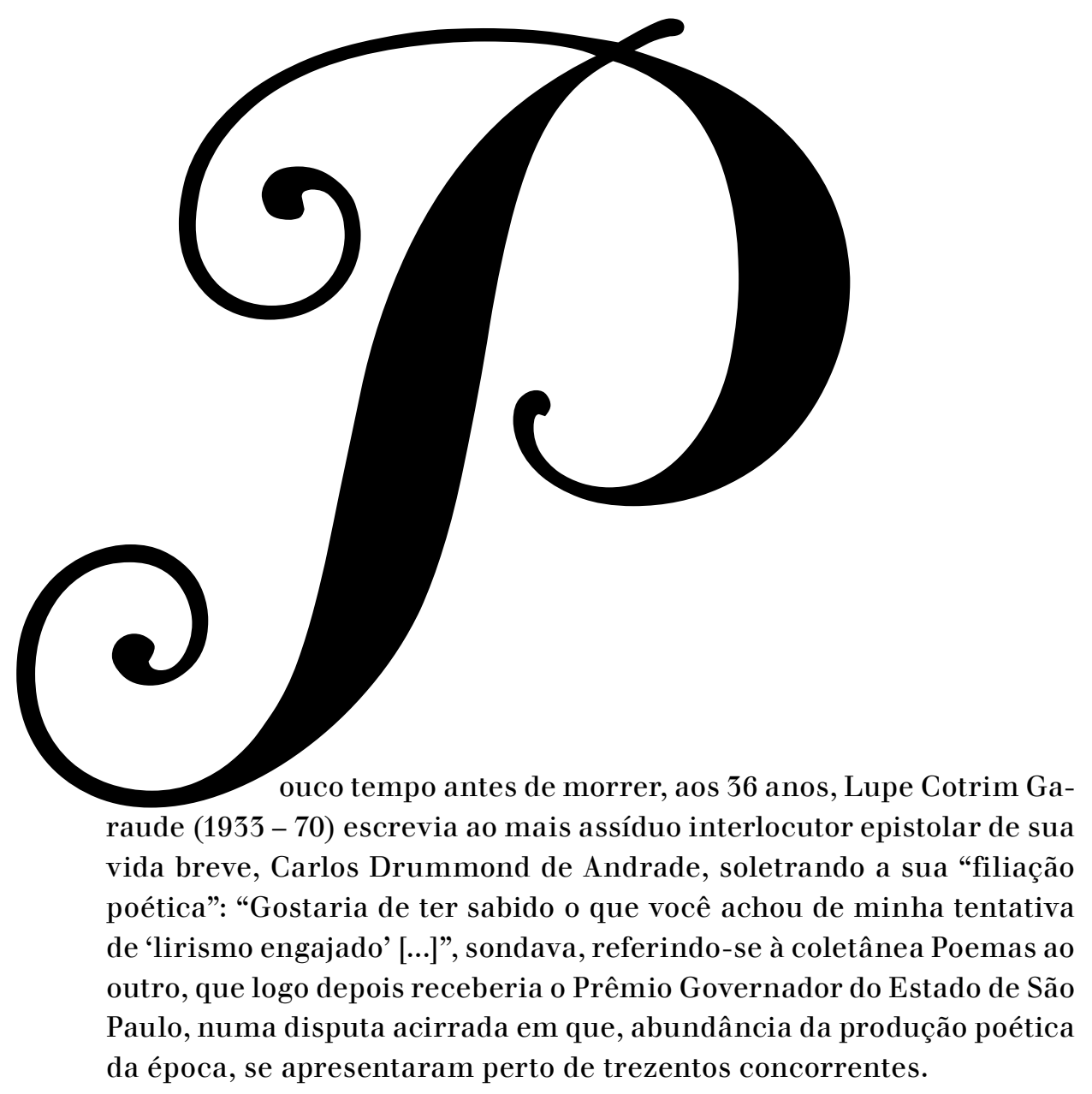

Sinto que minha poesia, depois de muita volta, voltou a você, isto é, sou poeta pós-drummondiana, filiada a um certo tratamento da palavra, mais seca, econômica etc., embora guarde um lirismo que em você se cobre de ironia. Enfim, sua filha, quer queira, quer não. ${ }^{2}$

Ao que se sabe, Drummond não chegou a responder a esta questionadora missiva. Em dezembro daquele ano (1969), enviava à escritora uma breve mensagem: "Lupe amiga: Neste fim de ano, estou pensando carinhosamente em você. Na poesia que você deu a todos, e na amizade que particularmente me tocou. As duas são coisas que ajudam a viver [...]". ${ }^{3}$ Assim se encerrava o diálogo epistolar, de quase quinze

2 GARAUDE, Lupe Cotrim. Carta de São Paulo, setembro 1969. Poemas ao outro recebeu ainda, também em 1969, o prêmio de Poesia da Fundação Nacional de Brasília.

3 ANDRADE, Carlos Drummond de. Cartão do Rio, datado de 30 de dezembro de 1969. Provavelmente, o poeta já sabia que sua amiga estava condenada por um câncer, de que ela mesma nunca soube com clareza. 
anos, que acompanhou toda a trajetória literária de Lupe Cotrim, cujo principal legado consiste em seus sete livros de poesia lírica, publicados entre 1956 e 19704. Travado num período decisivo da vida política e cultural brasileira, entre o governo JK e a ditadura, esse diálogo está preservado num conjunto de pouco mais de quarenta "cartas, cartinhas e cartões" inéditos, que serão abordados adiante - volume modesto, todavia expressivo sobretudo do caminho poético e intelectual de Lupe. Essa correspondência constitui uma das faces inexploradas do acervo da escritora, recentemente incorporado ao conjunto de fundos pessoais do Instituto de Estudos Brasileiros (IEB-USP) mediante doação de seus filhos ${ }^{5}$.

Convirá lembrar que Lupe Cotrim estreou, aos 23 anos, ainda sob o influxo da lírica essencial e do "estetismo subjetivo" que marcaram boa parte da poesia pós-modernista brasileira, especialmente a da "geração de 45". Ponto de partida de poetas da eclética geração seguinte, a "de 60", vizinha contígua da chamada poesia marginal e da "contracultura", e antípoda da poesia concreta e de outras vanguardas da época. Na vertente "discursiva” dessa geração intersticial, de apego à imagem e ao verso, à tradição, em suma, Lupe tem sido inserida ao lado de autores díspares como Mário Faustino, Marly de Oliveira, Carlos Nejar ou Rubens Rodrigues Torres Filho, entre outros estreantes das décadas de 1950 e 1960 - sem deixar de lembrar a tríade de então jovens, belas e promissoras poetas paulistas formada por Hilda Hilst, Renata Pallottini, e ela própria. Uma singularidade do caminho de Lupe foi a de buscar uma dicção própria no estudo de Filosofia, na então Faculdade de Filosofia, Ciências e Letras da rua Maria Antônia ${ }^{6}$ - onde se nutriu das filosofias da existência de Heidegger e MerleauPonty e sorveu sua porção de Marx -, com o intuito de libertar seus versos de resquícios neo-simbolistas e do intimismo dos primeiros livros. Com o projeto, enfim, de adensar sua "concepção do mundo", refletir

4 Monólogos do afeto (1956); Raiz comum (1959); Entre a flor e o tempo (1961); Cânticos da terra (1963); O poeta e o mundo (1964); Inventos (1967); e o póstumo Poemas ao outro (1970). Foram depois reunidos na coletânea que traz uma seleção de poemas dos cinco primeiros livros, realizada pela própria autora, mais a versão integral dos dois últimos, publicada por iniciativa de José Arthur Giannotti. GARAUDE, Lupe Cotrim. Obra consentida. São Paulo: Brasiliense, 1973.

5 Atualmente em fase final de organização no Arquivo da Instituição. Devo agradecer aos filhos da poeta, Lupe Maria Ribeiro Lima e Marco Giannotti, e aos descendentes de Carlos Drummond de Andrade, intermediados pela Agência Riff, por terem autorizado a publicação de excertos das cartas dos dois escritores. [Em sua interface passiva e ativa, a correspondência entre Lupe e Drummond encontra-se no IEB na forma de cópias do Arquivo Carlos Drummond de Andrade/Fundação Casa de Rui Barbosa, à exceção do último cartão do poeta (30 de dezembro de 1969), que é original.]

6 Afinal, verificada também entre alguns de seus contemporâneos, como Orides Fontela e Rubens Rodrigues Torres Filho. 
sobre a linguagem e depurar sua escrita, já econômica e contida, de modo a dizer de maneira mais limpa e moderna aquela preocupação com "o homem" (ou o Homem), latente desde as tentativas do início e problematizada com os estudos filosóficos. Preocupação decerto também herdada do lirismo reflexivo e solidário de Drummond.

Essa busca de um novo caminho, com efeito, levou-a a transitar do erotismo sutil de Inventos (1967), "entreato" dramático com as vozes de um narrador e dois amantes, até a poesia participante e de crítica social, em linguagem elíptica e antioratória, de Poemas ao outro (1970). Uma das mais admiráveis composições desse livro, "Memória Barroca”, escrita em dezembro de 1968, após visita ao bairro de palafitas em Salvador no momento da edição do Ato Institucional no 5, que instauraria os "anos de chumbo", foi dedicada a Drummond. Aquele trágico momento da vida brasileira custou à poeta desordens também na vida pessoal, com a perseguição e a "aposentadoria" de colegas e do marido filósofo, José Arthur Giannotti, ela própria então professora de Estética na atual Escola de Comunicações e Artes da USP (ECA), cujo Centro Acadêmico leva seu nome.

Uma cola negra escorre das calçadas, e o mar escurece no pigmento do rosto.

Uma fratura na pedra; e mais outra.

Estátua que se ergue ou entranha que se mostra.

O saveiro furta às águas

a sumária riqueza dos peixes

e no farol se acende

a história ameaçada; nem tudo será

resíduo e paisagem. A couraça

urbana acintura a nova cidade cinza e domesticada. [...]

Homens cercados de águas

por todos os lados:

perfis Alagados.

Numa vida em que o futuro

não é o primeiro rumo,

lá em Alagados.

Uma criança no detrito

inventa seu edifício

lá em Alagados 
e o corpo insiste sobre o lixo

uma sentença passada.

Confins Alagados.

O rádio noticia o ato

lá em Alagados.

Para homens sem enxada

lá de Alagados. [...]

Tudo é um deserto de águas

lá em Alagados, consumindo seus naufrágios.

Ai, Alagados. [... $]^{7}$

\section{"Memória barroca"/Poemas ao outro}

Se não "seco", este é um poema, com efeito, "econômico", e emblemático da passagem do "monólogo" inaugural ao diálogo com o mundo e o "outro", conforme palavras dos títulos de seus primeiro e último livros. Nele, é possível flagrar um paradoxo freqüente na poesia lírica da autora (e talvez também da mulher Lupe), como que dividida entre o anseio romântico de beleza e o sentimento do mundo, da miséria e das injustiças que inviabilizam ou ensombram o belo: "Seduzidos pela brisa / mergulhamos na poeira dourada / e nos azuis incontáveis: / mas rompe-se entre os olhos / uma miséria sem trégua / - essa é a nossa treva", dizem os últimos versos de "Memória Barroca". Poema também, no que foi omitido naquele atestado de "filiação" enviado por Lupe Cotrim em sua última carta ao amigo Drummond, cuja linguagem, incorporando a tensão do momento, buscava aproximar-se da "nova objetividade" e do verso despojado, "concreto", de outro poeta brasileiro de sua predileção, João Cabral de Melo Neto.

Se buscou o "engajamento" da poesia dita participante - como lembra Alfredo Bosi, ressonância da "exigência ética sentida por toda a cultura brasileira” nos anos de 1950 e $1960^{8}$ - e logrou distanciar-se do “espetáculo do autor", referido por Cabral, o projeto de atualização estética de Lupe, com sua morte prematura, ficou no meio do caminho. $\mathrm{O}$ que não invalida o fato de ela ter deixado um punhado de poemas antológicos. Os da última fase permitem entrever que, contemplando a materialidade da linguagem, sua escrita ia se inclinando para algum experimentalismo, a partir, também, das pesquisas para o doutoramento

7 GARAUDE, Lupe Cotrim. Poemas ao outro. São Paulo: Comissão Estadual de Cultura, 1970. p. 63-66.

8 BOSI, Alfredo. História concisa da literatura brasileira. São Paulo: Cultrix, 1970. p. 523. 
que chegou a iniciar, sob orientação de Gilda de Mello e Souza, sobre a poética de Francis Ponge. Terá sido talvez o entranhado lirismo, a que alude naquela carta a Drummond, o que motivou na antiga aluna de canto lírico, aficionada das árias de Mozart, o apego ao sublime e a inapetência para algumas das conquistas modernistas nos versos que deixou. Especialmente para o humor e o prosaico, do qual João Cabral faria a empenhada defesa em sua crítica justamente à "geração de 45" de cujos resíduos extemporâneos a autora buscava libertar-se quando morreu, vítima de câncer. Algumas de suas diferenças com aquela "geração" não deixaram de ser captadas por outro poeta prematuramente desaparecido, Cacaso: a

busca da beleza, em Lupe, diferentemente do academismo retórico dominante na Geração de 45, não é um ideal apenas literário, mas também moral e existencial. Vem daí, dessa amplitude de visão, outra dimensão essencial de sua poesia: a filosófica ${ }^{10}$.

\section{Diálogo com Drummond}

O Fundo Pessoal Lupe Cotrim Garaude no IEB, em fase final de organização no Arquivo d do Instituto, é formado por correspondência com parentes, amigos e escritores, cadernos, rascunhos, dois diários íntimos, fotografias, recortes, copiosas notas de leitura dos tempos do curso de Filosofia, manuscritos literários (autógrafos e datiloscritos), em meio aos quais alguns inéditos - além de poemas e contos, está a peça de teatro em três atos Amanhã seria diferente, sobre as primeiras tentativas de instrumentalização da Universidade após o golpe militar de 1964. Há também aulas redigidas referentes ao curso de Estética que ministrou, no final da década de 1960, na atual ECA/USP, e ainda alguns artigos e ensaios, como os que analisam obras de Lukács e de Rousseau ${ }^{11}$. O estudo desses papéis, além de viabilizar a reconstituição da semi-apagada trajetória literária e biográfica de Lupe Cotrim, tende a iluminar seu processo de composição; e, também, a abrir novas possibilidades de leitura e de compreensão de sua obra, até aqui mais detidamente pesqui-

9 MELO NETO, João Cabral de. A geração de 45. In: Prosa. Rio de Janeiro: Nova Fronteira, 1997. p. 71-89.

10 BRITO, Antonio Carlos Ferreira de [Cacaso]; ARÊAS, Vilma (Org.). Não quero prosa. Campinas: Editora da Unicamp; Rio de Janeiro: Editora da UFRJ, 1997. p. 97-99.

11 GARAUDE, Lupe Cotrim. Considerações sobre a oposição: narrar ou descrever. Revista da ECC-USP, São Paulo, n. 1, p. 123-129, 1967; e et. Rousseau - o ofício do imaginário. Revista da ECC-USP, São Paulo, n. 2, p. 93-104, 1968. 
sada no plano acadêmico, ao que se sabe, por apenas dois estudiosos, Maria Beatriz de Alcântara e o escocês John M. Parker ${ }^{12}$.

Percorrer alguns excertos da correspondência entre a escritora e Carlos Drummond de Andrade poderá constituir um primeiro passo na tentativa de trazer à tona, nessa privilegiada interlocução com o autor de Claro enigma, um pouco de seu percurso intelectual e humano e de seu tempo literário e, ao mesmo tempo, será uma chance de se incursionar, brevemente, pela trajetória de sua poesia lírica ${ }^{13}$. Convém lembrar que, embora tenha vivido por dez anos no Rio de Janeiro, onde estudou no colégio Bennett e esboçou as primeiras tentativas literárias, especialmente contos, a paulistana Lupe Cotrim deve ter encontrado pela primeira vez o "maior poeta brasileiro de todos os tempos", como algumas vezes se referiu a Drummond, em 1956. Isto é, quando, morando em São Paulo, foi ao Rio divulgar sua coletânea de estréia, Monólogos do afeto. Com 27 textos grafados em redondilhas e outros metros breves, o volume, ilustrado por Darcy Penteado, ainda algo indeciso entre verso e prosa, buscava ritmo e rima como solução; e incluía, em meio a composições ingênuas de tom confessional e monótono, quatro poemas narrativos já de melhor fatura, um deles, "Romance de número par", dedicado ao próprio Drummond. Mas havia ali ainda um "Hino dos Comedidos" que traz em embrião aquele descompasso do eu com o mundo, de crítica ao estabelecido e às convenções sociais, que, embora sem contrapartida na forma, se tornaria recorrente na poética da autora: "Não me agradam [...] / os partidários tão vários / de toda moderação. / [...] acredito em vida intensa, / [...] Compreendo a mulher que rasga / as vestes em grande dor / e sinto imensa ternura / pelo homem desesperado" 14 .

Já na condição de autora publicada, Lupe Cotrim recebia em outubro de 1956 a primeira cartinha de Drummond, em que ele comentava o "trabalho escolar" que, ainda no curso de Biblioteconomia do Sedes Sapientiae, a jovem poeta escrevera sobre o "Poema de sete faces", provavelmente a ele entregue em mãos: "tão gostoso, porque tão inteligente, em que o magro poeta se sentiu admiravelmente interpretado por

12 ALCÂNTARA, Maria Beatriz. A poesia de Lupe Cotrim Garaude: imanência $\mathrm{x}$ transcendência. 1987, 266 f. Dissertação - Universidade de Brasília, Brasília, 1987. [Dissertação de mestrado orientada por Domingos Carvalho da Silva]; PARKER, John M. The poetry of Lupe Cotrim Garaude. In: Ibero-amerikanishes Archiv. Londres/ Berlim. p. 39-60, 1975. (Estudo contemplado, em 1972, com o prêmio Rio Branco da Casa do Brasil em Londres.)

13 E com a licença para, mais à frente, algumas digressões por documentos e depoimentos de terceiros.

14 GARAUDE, Lupe Cotrim. Monólogos do afeto. São Paulo: Edigraf, 1956. p. 55-57. 
uma menina (é verdade que a menina também era poeta, como se viu depois)". Dizia que "todos" tinham gostado dela no Rio, e acrescentava o encorajamento protocolar: “[...] espero e confio em que V. nos dará belos poemas", sem antes deixar de mencionar a longa entrevista publicada naquele mesmo domingo de "cúmulo de azul", feita com Lupe pela jornalista Eneida de Moraes, da qual lhe enviava um recorte ${ }^{15}$. Entrevista que terminava com uma surpreendente (premonitória?) confissão para alguém então com 23 anos: "Quero morrer do modo menos desesperado que puder. Porque, aqui muito em segredo: eu não quero morrer" ${ }^{16}$. Com a espontaneidade desconcertante que por vezes deixava aflorar, Lupe ecoava à jornalista a "Maria", figura de um dos poemas de seu livro de estréia, que se debatia com o medo da morte ${ }^{17}$.

Mas a resposta a Drummond foi radiante:

Me fiz menina outra vez [ao receber a carta] e dei uns gritos (o que assustou todas as pessoas da casa, inclusive o cãozinho HaiKai, que envelhece e emburguesa) [sic]. Senti muito que pudéssemos conversar tão pouco, e nesse ambiente convencional das instituições públicas [provavelmente a sede do Patrimônio Histórico e Artístico Nacional, onde Drummond trabalhava]. Estou querendo deixá-lo cheio de dívidas. Obrigada pelos recortes de jornal. Quando se acaba de publicar o primeiro livro surge uma avidez de afeto e confirmações... [...] A sua carta resolve os meus problemas e o meu futuro de poeta se anima e toma pé. [... $]^{18}$

E aproveitava para consultar o poeta sobre uma palavra empregada em um novo poema: o que achava de "o poeta ressentiu a natureza"? Dúvida que Drummond, assediado por incontáveis escritores Brasil afora, relutou em responder:

Lupe, este velho bardo não é lá muito bom conselheiro em matéria de versos, mas você é tão simpatia, e mostra confiar tão generosamente nele, que não há remédio senão eu assumir um ar conspícuo [...] e dizer com voz grave: [...] Talvez pondo "re-sentiu" você exprima a nuança de sentimento que pretende comunicar $[\ldots]$

etc. $^{19}$

15 ANDRADE, Carlos Drummond de. Carta do Rio de Janeiro, 7 de outubro de 1956.

16 Diário de Notícias. Rio de Janeiro, 7 out. 1956.

17 GARAUDE, Lupe Cotrim. A morte de Maria. In: Monólogos do afeto. Op. cit., p. 17-18.

18 Idem. Carta sem data. [1956]

19 ANDRADE, Carlos Drummond de. Carta do Rio de Janeiro, 7 nov. 1956. 
Em nova ida ao Rio, Lupe desencontra Drummond na repartição pública, e deixa um bilhetinho, pois queria lhe mostrar o poema que escrevera sobre o "Sputinik" - era o início das explorações espaciais -, o qual aparece em seu segundo livro sob o título "Hino ao Augustus":

Um maior que nós / ousou o infinito. // Ó Sputinik, / herói real de antigo mito / a ampliar-nos / em outro espaço // [...] Violador dos deuses, / excesso de uma esperança / e de uma consciência [...] // prolongamento celeste de nós [...]

, escrevera nos versos livres que aproximam ciência e mito ${ }^{20}$. Decerto se encontraram depois e foi talvez nessa sua passagem pelo Rio que Drummond aproveitou para, "investido em repórter", fazer com ela uma entrevista-relâmpago, publicada originalmente em sua coluna do Correio da Manhã, flagrando e comentando a vivacidade intelectual da jovem amiga:

A vida tem sentido? - Enorme. O de continuar a humanidade e criar coisas. Gostaria de ser mãe ou filha de Dostoievsky? - Gostaria de ser filha dele. Deve-se dar esmola? - É inevitável. Não soluciona, mas não se pode deixar de dar. [...] Uísque é gostoso ou é costume? - É mamadeira de criança grande e triste. Os mortos se comunicam com os vivos? - Ficam dentro de nós. [...] Homem pode ser amigo de mulher? - Pode. E mulher de mulher? - Só as superiores. [...] Quando está triste, que disco põe na vitrola? Morte de Tristão e Isolda, de Wagner. [...]

O poeta republicaria a mesma entrevista na morte de Lupe, então no Jornal do Brasil ${ }^{21}$.

Quando a escritora não conseguiu disfarçar os ciúmes ao ver na imprensa um pequeno poema de Drummond dedicado à amiga comum Hilda Hilst, o poeta brandiu essa mesma matéria:

Não, não andei fazendo poemas para a Hilda; agradeci em verso, no meio de uma crônica, o livro que ela me mandou; eu andava em falta com a nossa poetisa. [...] Mas para você, ou sobre você, fiz uma crônica inteira, Lupe, divulgando aquela bela entrevista! [...]

20 GARAUDE, Lupe Cotrim. Raiz comum. Rio de Janeiro: Civilização Brasileira, 1959. p. 67-69.

21 ANDRADE, Carlos Drummond de. Lupe, rápida. Jornal do Brasil, Rio de Janeiro, 28 fev. 1970. Caderno B. 
E comentava as notícias sobre a V Bienal de São Paulo enviadas por Lupe: "Não fui nem irei à Bienal, que está bem resumida em sua carta; sinto um enjôo de morte de tachistas ou concretistas, gente que ignora a vida ou é incapaz de apreendê-la. [...]”22.

Por essa época, Lupe Cotrim publicou seu segundo livro de poemas, Raiz comum, que traz um belo retrato seu desenhado por Darcy Penteado. Com epígrafes de Rilke e do trovador provençal Giraut de Borneil - valerá um dia analisar as fartas epígrafes e dedicatórias inseridas nos livros da autora -, a coletânea comprova o empenhado esforço da recém-estreante em desenvolver a técnica do verso, também por intermédio do exercício artesanal do soneto (dentre os 35 textos, 17 têm esse formato, por vezes sem a separação estrófica). A crítica viu neles ressonâncias de Camões, referido em um dos poemas, e de Antero de Quental, mas a retomada do soneto empreendida antes por Jorge de Lima, Vinícius de Moraes e pelo próprio Drummond não estará ausente desse segundo e aplaudido livro.

Não sou uma vitória ou uma derrota, mas me conquisto sempre cada dia, procurando essa forma mais remota do que em mim nos instantes se perdia.

diz o soneto "Nem um profundo mar", de sabor clássico e um dos mais bem realizados da coletânea, que abria com uma "Ars Poética" reveladora: "Da desordem / nunca erguerei um verso. [...]". Alguns leram este dístico como crítica a certos desleixos formais do modernismo, afinal reprovados pelo próprio Mário de Andrade. Mas é no quarteto final do poema que reemerge aquela preocupação humanista e solidária, latente desde os primeiros versos, e que ela terá procurado fundamentar nos posteriores estudos de Filosofia:

O Homem,

sofrido a prosseguir

na sua eternidade construída

- eis o meu tema.

Cassiano Ricardo, interlocutor bissexto da jovem escritora, manifestou-se prontamente:

Raiz comum encantou-me pelo seu original lirismo. 'Nem um profundo mar', por exemplo, revela a meu ver excepcional con-

22 Idem. Carta do Rio de Janeiro, 15 out. 1959. 
cepção poética. Impõe-se, também, pelo valor formal, tão lucidamente perseguido e atingido. ${ }^{23}$

Também Guilherme de Almeida se pronunciou, em crônica: "Poesia da disciplina [...] há aí uma constante vigilância de si própria. [...] tenho a impressão de estar Lupe diante de sua poesia como diante de um espelho: sempre se estudando, analisando, autocriticando" ${ }^{4}$. Já Drummond, em uma cartinha à qual anexava o recorte de uma resenha de Antonio Olinto sobre o livro, foi sucinto: "Fico contente em saber de suas alegrias com o soneto e sinto através delas sua consciência - e sua exigência - de poeta" ${ }^{25}$.

A conversa epistolar entre os dois escritores sofreria um leve sobressalto quando Lupe pediu ao mineiro que lesse o diário íntimo que escrevera na adolescência, ainda no Rio - e que, decerto, hoje faria a delícia dos seguidores de Philippe Leujeune, o estudioso das "escritas do eu" -, e opinasse sobre a validade de publicá-lo, conforme lhe tinha sugerido um psicanalista.

[...] Tem lido o diário? Como já lhe disse, caso não ache valor literário, não se preocupe em me dizer - [do] que faço realmente questão é da poesia. Só publicaria o diário caso a exposição psicológica e a procura dos valores nessa época de formação, a adolescência, estiverem expressas de um modo que pudesse ajudar os outros. Caso contrário, vou guardá-lo. ${ }^{26}$

Tratava-se do caderno a que Helena Silveira, amiga de Lupe desde os tempos em que esta cursava o ginásio - juntas apresentaram um programa nos primórdios da televisão em São Paulo ${ }^{27}$, se refere em seu livro Paisagem e memória, no qual traça um breve perfil da poeta:

23 RICARDO, Cassiano. Carta do Rio de Janeiro, 24 set. 1959.

24. ALMEIDA, Guilherme de. O Estado de S. Paulo, São Paulo, 21 jul. 1959. Coluna Eco ao longo dos meus passos. [Posteriormente, Anatol Rosenfeld faria breve comentário sobre um dos poemas do livro, o verlaineano Tempo de amor. In: CANDIDO, Antonio et al. A personagem de ficção. São Paulo: Perspectiva, 1968. p. 22.]

25 ANDRADE, Carlos Drummond de. Carta do Rio de Janeiro, 24 ago. 1959. [A resenha de Antonio Olinto, Raiz Comum, foi publicada em O Globo, Rio de Janeiro, 22 ago. 1959. Coluna Porta de Livraria - A crítica da semana.]

26 GARAUDE, Lupe Cotrim. Carta de São Paulo, 23 nov. 1960.

27 Mulheres confidencialmente. Lupe Cotrim foi também produtora e apresentadora de outro programa de televisão, A semana passada a limpo, ao lado de Joaquim Pinto Nazário, no antigo Canal 2 - no qual, em homenagem ao amigo, leu a "carta de louvor" a Drummond enviada pelo ministro da Educação, Oliveira Brito, quando, às vésperas de completar 60 anos, o poeta se aposentou como chefe de seção do DPHAN. Cf. GARAUDE, Lupe Cotrim. Carta de 26 fev. 1962. 
[...] Conheci-a aos onze anos de idade, brincando com meus filhos e minha sobrinha Zelinda (filha única de Dinah [Silveira de Queiroz]) num jardim meio mágico [...] em Petrópolis. Àquela época foi cair-me nas mãos um "diário" de Lupe. Em meio a coisas ingenuamente bonitas, ela dizia: "Concordo com Shakespeare quando ele descreve o amor de Romeu e Julieta”. [...] Perdi a quase criança de vista e fui encontrá-la, já jovem mulher, preparando um livro, Monólogos do afeto. Foi uma das criaturas mais lindas que conheci: os olhos verdes, os cabelos de um loirocinza, o porte miúdo e delicado, a pele sempre dourada de sol. [...] Sua poesia foi amadurecendo e ela estudando, tombando a cabeça bela sobre livros e livros. Foi a primeira pessoa que me falou de L'Histoire de la folie, de Foucault. [... ${ }^{28}$

Helena não conta o que Lupe registrou no próprio diário: que entrou em fúria com aquela invasão de privacidade, por fim, adulta, aberta ao amigo Drummond. Mas o poeta não se empolgou com aquelas anotações da garota que amava Shakespeare e Chopin: "Lupe, loura, luna", assim começava, sedutor.

[...] Sem dúvida, Lupe, seu livro é válido e se sustenta pelo que há nele de situação humana vivida e [citando-nos ambos] passada a limpo. Essa autenticidade ninguém lhe pode negar, é um título. Mas o valor de uma obra, a meu ver, está sobretudo no ajustamento da forma a uma situação humana exemplar. [...] [e citava o diário de Amiel, prosseguindo com considerações de Estética sobre a autonomia da obra de arte.] Esperava, entretanto, mais do que encontrei, movido talvez pela sua poesia, que me autoriza a exigir muito de v., tão acentuado é o seu crescimento nela [...]. ${ }^{29}$

A jovem poeta não se mostrou decepcionada com o obstat, mas, com a sinceridade e a autonomia intelectual características, não hesitou em, citando Qu'est-ce que la littérature?, de Sartre, argumentar altivamente com Drummond:

Caríssimo Drummond [...] Agradeço-lhe de coração inteiro todo o trabalho que teve, mais a paciência. [...] Só de uma coisa não gostei: foi de você pelo mais leve momento achar que pudesse haver arranjo literário. O diário está exatamente como foi feito [aos] 13

28 SILVEIRA, Helena. Paisagem e memória. Rio de Janeiro: Paz e Terra; São Paulo: Secretaria Estadual de Cultura, 1983. p. 196-197. [Lupe depois registraria que esse encontro ocorreu quando tinha treze anos.]

29 ANDRADE, Calos Drummond de. Carta do Rio de Janeiro, 15 nov. 1960. 
anos. [...] é a história de uma menina procurando um sentido para a vida, sozinha e por isso tão [reforçada?] em si mesma. Além do mais nunca pensei em publicá-lo no meu nome [...]. Vamos deixar o diário de lado. Quero discutir um ponto de vista seu sobre arte que muito me surpreendeu. É quando você diz que a obra não se propõe a nada no sentido ético e moral, que isso pouco interessa ao autor [...]. Cito Sartre, com quem concordo. [...] bien que la littérature soit une chose et la morale une tout autre [chose], au fond de l'impératif esthétique nous discernons l'impératif moral. No fundo, Drummond, toda obra sua se definiu pela participação violenta, lúcida e, portanto, construtiva do mundo. Você pode dizer que independe de sua vontade consciente, mas existe então a vontade inconsciente, e você nesse aspecto sempre foi um moralista. Não no sentido burguês, no humano. [...] Querido Carlos, agradeço-lhe uma vez mais nossa amizade, [...] já invencível. Além de você pessoalmente reforçá-la, ela já se estruturou para sempre nos versos do grande poeta de A rosa do povo e Sentimento do mundo, que tanta esperança trouxeram para toda uma geração moça - embora o autor talvez nem saiba. ${ }^{30}$

Os bons votos trocados pelo Natal selaram o apaziguamento. E, em 1961, com a publicação da terceira coletânea de Lupe, Entre a flor e o tempo, Drummond enviava à amiga umas quadrinhas em hexassílabos, glosando os títulos de seus primeiros livros:

Condenado ao monólogo?

Mas de jeito discreto.

Contigo é que aprendi

monólogos do afeto.

Ausente, ensimesmado

na solidão do um?

Repara bem, e sente

nossa raiz comum.

Ela fala por mim, alheia a contratempo, leva-te meu carinho por entre a flor e o tempo. $[\ldots]^{31}$

30 GARAUDE, Lupe Cotrim. Carta de 23 nov. 1960.

31 Anexo a cartão enviado do Rio de Janeiro, 16 dez. 1961. 
Mais ambicioso do que os anteriores, o terceiro livro da escritora reúne séries de sonetos, odes e canções e inclui um poema que alude criticamente à poesia concreta - assunto esporádico das cartas com Drummond, nesse caso com concordância mútua ${ }^{32}$-, "A palavra é carente": "Isoladas / as palavras são mudas. // [...] sobrevivem / unidas umas às outras / numa força de ponte / para alcançar o ritmo / do horizonte. // Bem, mal, certo, errado / urgem arco-íris de sons / no rumo circular / da ambigüidade. // [...]"弦. Este é um dos melhores textos do livro, indicando que a escritora costumava obter melhor fatura quando se afastava da nebulosa interior, do "espetáculo do eu". (O que se confirmaria, sobretudo, em seu quarto livro, o bestiário Cânticos da terra (1963), que revela esforço de objetividade e a opção por versos polimétricos, apresentados em bela edição de Massao Ohno ilustrada por Aldemir Martins.) "A palavra é carente" foi dedicado a Cassiano Ricardo, e com epígrafe dele, que assinava a orelha: "[...] poesia feita de emoção e a um tempo radiosa inteligência. [...] Lupe concilia gentilmente la logique du coeur com aquilo que Pound chamou o 'jogo do intelecto com as palavras" ${ }^{34}$. Assim Cassiano apreendia a coexistência entre sentimento e lucidez, outra das marcas registradas dessa jovem poesia.

A partir daí verifica-se um espaço lacunar na correspondência de Drummond a Lupe, que não deixava de cobrar a falta de resposta a algumas de suas cartas - "você está mesmo condenado ao monólogo", provocava em um bilhetinho ${ }^{55}$. Afora um ou outro detectado extravio - um deles, lamentavelmente, de carta em que teria comentado com mais vagar um dos melhores livros da autora ${ }^{36}$-, esse silêncio coincide com um período de rápidas mudanças na vida pessoal da escritora. Especialmente o nascimento da primeira filha, Lupe Maria, para a qual escreveu uma breve série de poemas, depois inserida em $O$ poeta e $o$ mundo (1964) ${ }^{37}$, e o início do curso de Filosofia na USP, em 1963, o que logo comunicaria ao amigo. Depois de agradecer o recebimento de $\mathrm{Li}$ ção de coisas - "Isto é aquilo' deixou-me perturbada, não lhe conhecia

32 “[...] Tenho andado assustada com a veemência dos concretistas e praxistas - mas creio que é preciso agüentar a mão, as vanguardas são úteis porque nos sacodem [...]". GARAUDE, Lupe Cotrim. Carta de São Paulo, 18 set. 1966.

33 Idem. Entre a flor e o tempo. Rio de Janeiro: José Olympio, 1961. p. 39-41.

34 RICARDO, Cassiano. In: GARAUDE, Lupe Cotrim. Entre a flor e o tempo. Op. cit.

35 GARAUDE, Lupe Cotrim. Bilhete [enviado de São Paulo], 12 dez. 1961.

36 "[...] Agradeci em tempo seu livro, que me encantou: e você não recebeu minha carta! Mas o encantamento perdura. [...]”. In: ANDRADE, Carlos Drummond de. Cartão enviado do Rio em janeiro de 1968. [Portanto, a carta que se terá perdido comentaria o sexto livro da escritora, Inventos, publicado em 1967.]

37 "Iniciemos", "Nascimento maduro", "Amanhã comum" e "Raiz de infância". In: GARAUDE, Lupe Cotrim. O poeta e o mundo. Rio de Janeiro: José Olympio, 1964. p. 5-13. 
ainda sob esse prisma tão relativista" - e declarar-se "apaixonada pela [...] e filhinha" ${ }^{38}$, contava:

[...] entrei na Faculdade de Filosofia, há anos que eu a vinha namorando de longe. Minha realização como poeta só se efetivará na medida da minha concepção do mundo - quero dar-lhe a objetividade de que necessita. Você não imagina como é admirado e querido entre os professores (todos jovens, cultos, inteligentes, um Brasil de causar a maior esperança). Sua poesia é sentida e compreendida lá no fundo. [...] Estou como poeta entre filósofos. Imagine que escrevi um poema chamado "Paisagem de uma aula de Filosofia” para mostrar o que podemos fazer com eles. Ficaram estarrecidos... e encantados. ${ }^{39}$

Com esparsas rimas, sobretudo toantes, breves versos polimétricos e uso feliz do estrato sonoro da linguagem - como a maior parte de suas composições desde então -, este é um dos mais fortes poemas da autora na fase intermediária entre o início e o limiar da maturidade que pôde alcançar. José Arthur Giannotti, que conheceu Lupe quando ela prestava o vestibular, e com quem depois viria a se casar, refere-se a esse poema no talvez único depoimento público que fez sobre ela. Isso ocorreu em uma homenagem nos vinte anos de sua morte, realizada na ECA/USP, onde a escritora figurou entre os docentes pioneiros. Assinalando que Lupe realizou os estudos com grande sacrifício pessoal - trabalhava durante o dia na Caixa Econômica Federal, onde sempre que podia mergulhava nos livros, e à noite seguia para a faculdade -, e procurou a Faculdade de Filosofia em decorrência da percepção de que sua poesia tinha chegado a "um impasse", recordou o filósofo:

Eu a conheci no vestibular. Eu estava na banca quando obviamente fui obrigado a notar a presença e a beleza dela. [...] logo numa de minhas primeiras aulas, que era justamente uma introdução à fenomenologia, ela me aparece trazendo um poema [...], "Paisagem

38 Idem. Carta de setembro de 1962. Em carta de 20 de novembro de 1965, voltava a comentar Lição de coisas: "[...] cada dia mais o admiro e compreendo uma certa resistência que se formou: é um livro tão exato e econômico, o lirismo está tão denso e disciplinado, que à primeira vista não satisfaz aos derramados”.

39 Idem. Carta de 3 de setembro de 1963. [Paulo E. Arantes confirma essa admiração por Drummond entre os mestres filósofos: "[...] desnecessário dizer que reinava Drummond", ajuntando: "mas o da fase classicizante e sobretudo das 'tentativas de explicação e interpretação do estar-no-mundo', seguido de Fernando Pessoa e Rilke" - também poetas muito lidos por Lupe Cotrim nos anos 50 e 60. ARANTES, Paulo Eduardo. Um departamento francês de ultramar. São Paulo: Rio de Janeiro: Paz e Terra, 1994. p. 178.] 
de uma aula de Filosofia", no qual o tema da fenomenologia e da volta ao cotidiano era colocado em versos, não mais como uma estrutura de conhecimento, mas voltado para uma estrutura de emoção e de transpiração lírica. Ela passa por um departamento que é extremamente rigoroso em suas exigências. E ela trabalha muito. Lembro-me que no final do curso ela me havia dito o quanto havia escrito durante aqueles [...] anos. Ela havia reunido todos os trabalhos e realmente dava um volume impressionante [...]..$^{40} \mathrm{O}$ aspecto mais importante do percurso intelectual de Lupe foi o fato de ela refletir um lado da rua Maria Antônia que não tem sido muito privilegiado. Porque falamos muito a propósito da importância política, ou mesmo da importância [...] intelectual da rua Maria Antônia, mas nos esquecemos que também havia um lado de arte. A Lupe foi, justamente, uma dessas pontes para a poesia [...]. ${ }^{41}$

"Paisagem de uma aula de Filosofia" dialetiza, na primeira estrofe, o eu e a natureza para, a seguir, chegar à síntese poética pelo desatar de imagens de colorido fantástico, num procedimento raro na lírica da autora:

Porque a pedra / está fora do tempo / e eu por dentro; / [...] e a mim falta / esse fôlego verde, / em tênue movimento. // Mas nessa extensão tão plena / é que mais me compreendo. / [...] a morte é apenas uma flor / vermelha, que passa no vento / [...] Olhando dentro de mim, / de dentro da natureza / eu a refaço - e invento a beleza. ${ }^{42}$

\section{A "dúvida drummondiana"}

Do Rio, Drummond, como a ecoar o Mário de Andrade da "Elegia de Abril”, passou a estimular os estudos da jovem escritora. E não disfarçou a alegria quando ela lhe comunicou que preparava um trabalho sobre sua obra poética, para a disciplina do professor Cruz Costa. Escreveu-lhe Lupe, em 1965:

[...] formo-me no ano que vem (felizmente mais lírica do que nunca, depois desse massacre sistemático entre o ser e o não ser). [...]

40 O que se confirma pelas copiosas anotações e trabalhos de aproveitamento reunidos no Fundo Lupe Cotrim no IEB.

41 Depoimento de José Arthur Giannotti. In: RECTOR, Marina C. (Org.). Simpósios em Comunicações e Artes. n. 7. São Paulo: ECA/USP, 1990. p. 7-13.

42 GARAUDE, Lupe Cotrim. Paisagem de uma aula de filosofia. In: O poeta e o mundo. Op. cit. p. 28-29. 
Devo fazer um trabalho para Filosofia Geral, que este ano segue a história das idéias, [curso] dado pelo professor Cruz Costa - você deve conhecer. Ele, que é uma inteligência arguta e sensível, é taxativo: história mesmo das idéias é na literatura que se encontra. Assim me decidi a escrever a seu respeito, como poeta meu dileto [...]. Vou verificar a “dúvida drummondiana” com rápidas e sumárias relações ao ceticismo e ao cartesianismo. [...] Espero [depois] fazer [disso] um artigo ou material para palestra [...]. ${ }^{43}$

Dessa vez, o que não desmente a legenda de que uma das alegrias de um escritor é ver sua obra estudada, a resposta do amigo não tardou: "Fiquei todo embandeirado ao saber que serei objeto de estudo universitário feito por você. Que bom! E mais contente pelo gosto com que você vai fazendo o seu curso, interessada em aumentar o equipamento cultural que tantos literatos desdenham, por preguiça"44. Dois meses depois, Lupe avisava que o artigo estava "pronto". "Já entreguei, o professor gostou muito", mas pretendia ainda "aperfeiçoá-lo para publicação”.

O projeto, como lhe disse, é mostrar como a dúvida aparece para a arte e para a filosofia: como a primeira procura assumi-la fundamentalmente [...], já que o conhecimento é precário, não captura de fato a coisa: apenas a criação [...] pode transpassar a dúvida, sem superá-la definitivamente, como sonham os nossos vizinhos, os filósofos, que têm a fé inabalável na razão. $\mathrm{O}$ seu poema "A máquina do mundo" demonstra isso com grande evidência, mas mostro como essas conclusões já estavam mais ou menos implícitas em toda a sua obra. Não aprontei ainda [a revisão do texto] porque estou em exames. ${ }^{45}$

Quase um ano depois, Drummond recebia enfim o artigo e respondia com perceptível entusiasmo:

Sim senhora, seu estudo me encheu as medidas: lúcido, seguro, provando bem que o seu curso de filosofia não foi mero divertimento do espírito; ele deu a você um instrumento de análise que falta habitualmente à nossa crítica. E eu lhe confesso que enxerguei mais claro na massa de meus versos, ajudado pela luz que você projetou sobre eles. Agrada-me ver confirmada essa "infiltração" da esperança no seio da minha dúvida, que você apresen-

43 GARAUDE, Lupe Cotrim. Carta de São Paulo, 20 ago. 1965.

44. ANDRADE, Carlos Drummond de. Carta do Rio de Janeiro, 8 set. 1965.

45 GARAUDE, Lupe Cotrim. Carta de São Paulo, 20 nov. 1965. [Ao que se sabe, o trabalho não foi publicado.] 
ta como elemento criador e não negativista. Como também me emocionou ver tanta atenção e carinho postos no desvendar em minha poesia alguma coisa mais do que o simples dizer imediato, a forma e o jogo verbal, atribuindo-lhe um sentido, uma posição diante do enigma da vida e do mundo. Muito, muito te agradeço, amiga e poeta, o que isto representa de afetuoso interesse ligado à avaliação intelectual [...]. ${ }^{46}$

E, sempre cuidadoso, guardou a cópia carbono do estudo em seu arquivo, transferido depois de sua morte para a Casa de Rui Barbosa, que forneceu ao IEB uma reprodução. Depois de um preâmbulo sobre a presença da "dúvida" na arte e na filosofia - embora com "motivações diversas [...] tanto o artista como o filósofo têm, como disposição fundamental, pôr o dado em questão" - e de uma breve abordagem sobre a “dúvida metódica” de Descartes, além de fartas transcrições de versos do poeta analisado, e de outras de Goethe e Shakespeare, lê-se no epílogo do texto, na linguagem tateante da ensaísta aprendiz:

[...] Através do lirismo exato, da ironia sutil, de um profundo interesse pela vida de qualquer e todos os homens, Drummond cumpriu a melhor realização artística. De seu lugar, "ponto de ver e não de ser", sua obra se lança com extraordinária força; a dúvida que dilacerou o conhecimento, que desmentiu, em relação ao Ser, suas conquistas mais extremas, faz parte da própria criação artística, servindo-lhe de contraponto. Se o Ser não se reduziu também à conquista do poeta, este lhe responde com sua poesia, pois, como ele nos diz em "Isto é aquilo" [...], a forma abarrota "o largo armazém do factível / onde a realidade é maior do que a realidade". ${ }^{47}$

Nesse meio tempo, Lupe teve seu segundo filho, que veio a ser o artista plástico Marco Giannotti, logo saudado pelo autor de Fazendeiro do ar: "Viva Marco! O aparecimento dele, numa hora tão anticoncepcional, é um testemunho de poesia e de continuidade do humano. Agora que venha o livro anunciado, com seus novos belos poemas"48. Antes, ela havia publicado o quinto livro de poemas, O poeta e o mundo, aparecido em 1964. Obra de transição em que retomava o exercício do soneto e

46 ANDRADE, Carlos Drummond. Carta do Rio de Janeiro, 19 out. 1966.

47 GARAUDE, Lupe Cotrim. A dúvida na poesia de Carlos Drummond de Andrade. [Datiloscrito, 14 p.] Expresso aqui reiterados agradecimentos à equipe do AMLB da Casa de Rui Barbosa pela cessão dessa cópia. [O texto serviu de base a algumas palestras de Lupe sobre Drummond, a primeira delas realizada num ciclo organizado pela galeria Chelsea, em São Paulo.]

48 ANDRADE, Carlos Drummond de. Rio, 25 ago. 1966. 
voltava a um motivo recorrente, o mar, possível ressonância da lírica portuguesa que provavelmente tanto pesquisou, e também de Cecília Meireles, que, em fins da década de 1950, ainda incluía entre os poetas de sua predileção, ao lado de Manuel Bandeira. Retomava, ainda, a vertente metapoética, a da reflexão sobre a missão do poeta e a natureza da poesia, principalmente em "Visão da palavra", outro poema dedicado a Cassiano Ricardo - texto que, afinal, ecoava Drummond: "A palavra é móvel, fluida, / em seu corpo interpretado. [...] // Mantida em dicionário / eis que palpita / qual pássaro contido / no alcance de seu vôo. [...] // A palavra é humana [...]"*9. Voltava também aos velhos temas do amor, da beleza e da morte:

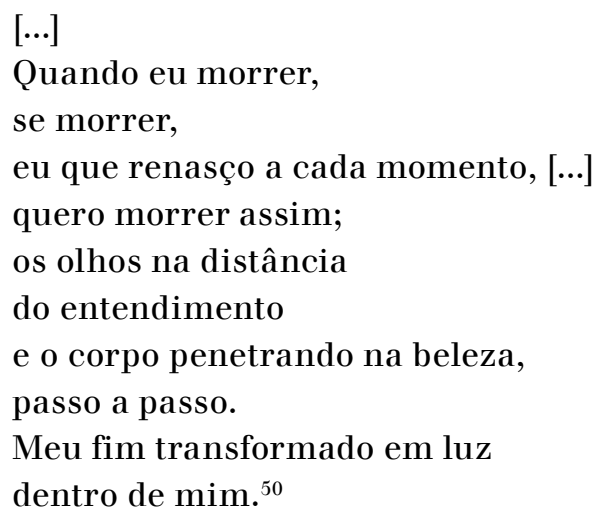

Em 1967, Lupe Cotrim publicava sua sexta coletânea, Inventos, que representava já considerável avanço na busca de uma dicção própria, especialmente a série "De amor" - a primeira seqüência, "De mar", revela, sobretudo nos primeiros poemas, ressonâncias contundentes das sonoridades cabralinas, as quais, também como herança dos romanceiros ibéricos, exploram a dissonância entre toantes e consoantes. Em uma carta a Drummond, Lupe chegou a referir suas intensivas leituras do genial pernambucano:

[eu] me fascino cada vez mais pela obra de João Cabral - é algo de muito sério, se concretismo de fato houvesse e valesse a pena, ele já o realizou plenamente. O objeto é visto, dissecado até o fim, com uma $[. .$.$] economia de meios realmente excepcional. { }^{51}$

O "entreato" de Inventos, poema dialogado sobre a paixão entre dois amantes, inclui, em registro sublime, versos livres e metrificados,

49 GARAUDE, Lupe Cotrim. O poeta e o mundo. Op. cit., p. 21-22.

50 Idem. "Última paisagem". In: ., Ibidem, p. 45.

51 Idem. Carta de São Paulo, 20 nov. 1965. 
com larga variedade sonora e rítmica e ainda um soneto em meio a seus dezessete textos, alguns dos quais antológicos. "Ser transparente / é quase um suicídio [...]", diz a voz masculina em "Diálogo I". Ou a voz feminina, no "Monólogo I", segmento de sabor clássico e talvez um dos pontos mais altos da poesia lírica de Lupe:

Hei de inventar amor, ávida e atenta.

Amor de ser a outro que é demais o amor que em coisas hoje se alimenta. [...]

Hei de inventar amor num desafio às mais concretas frases, aos dias úteis, amor de ser a outro que é demais ter um mundo por dentro desprovido. [... ${ }^{52}$

O aparato repressivo da ditadura militar se instalava a passos firmes, infiltrando-se sub-repticiamente mesmo nos recintos mais íntimos: "É o tempo do medo", diz a voz feminina no "Monólogo III". Foi nesse tempo já sombrio, que Lupe Cotrim, havia pouco formada na Faculdade de Filosofia, foi convidada a integrar o primeiro grupo de docentes da então recém-fundada Escola de Comunicações Culturais da USP, a atual ECA. E escrevia a Drummond contando a novidade:

[...] virei professora - e logo de 300 alunos de uma vez só. [...] Leciono Estética e Evolução dos Estilos. Tenho tido, pois, muito trabalho, estudando muito. [...] Mas é bom, tem muito aluno inteligente, em geral são curiosos, críticos. Acho que enfim é uma profissão para o poeta, o campo de interesse converge - é um trabalho criador $[\ldots]^{53}$.

Um de seus alunos, o professor Ismail Xavier, egresso da primeira turma de Cinema da escola, traçaria depois um nítido perfil da carismática professora Lupe Cotrim, lembrando o interregno em torno de 1968, quando, por pressão dos estudantes, mas em decorrência de diálogos para os quais sempre se mostrou aberta, ela aceitou alterar a bibliografia inicialmente proposta, a partir de Foucault, para ensaios sobretudo de Marx e Marcuse; ele então se refere ao motivo que levou os alunos a darem o nome da professora-poeta ao Centro Acadêmico da ECA.

[...] [Ela] se transformou numa referência porque, sem [querer] mistificar, acredito ter sido ela, naquele primeiro momento, quem conseguiu simbolizar uma resposta [...] ao desafio de dar conta dessa

52 Idem. Inventos. Rio de Janeiro: José Olympio, 1967. p. 28, 38 e 31.

53 Idem. Carta de São Paulo, 27 maio 1967. 
relação viva [da recém-fundada escola] com o contemporâneo na área da cultura. [...] Ao mesmo tempo em que havia da parte da Lupe professora uma preocupação imensa com problemas de rigor acadêmico, intelectual e conceitual, inclusive até enfrentando determinadas inseguranças [...], pelo fato de estar começando sua carreira como professora, em nenhum momento ela se escondeu em formalismos [...]. [É] importante lembrar, no caso de Lupe professora, essa vivacidade, essa capacidade de se expor, de assumir os riscos que essa Escola nova trazia, [onde] os professores [...] tinham de enfrentar uma escola nova e uma conjuntura política, social e cultural extremamente desafiadora, e [...] uma geração que cobrava muito. [...] Acredito que Lupe Cotrim se transformou numa referência nessa escola porque, acima de tudo, ela definiu [de modo] muito claro uma personalidade. [...] É claro que a dimensão política dessas características da professora Lupe gerou, não por acaso, a decisão de batizar-se o Centro Acadêmico [da atual ECA] com o seu nome. Isto se deu muito em função do comportamento que ela sempre teve durante aquele período de crise. [...] sempre tivemos na nossa experiência, na nossa memória, uma visão extremamente positiva da maneira como ela se relacionou com [as] diversas áreas [da ECA] e, em particular, com a área de cinema. ${ }^{54}$

Em sua experiência de três anos como docente da escola, Lupe Cotrim chegaria a atuar como atriz em um curta-metragem de um dos alunos de cinema ${ }^{55}$.

\section{"Poesia até o fim"}

O início da docência coincide com as pesquisas com vistas a um doutorado direto, na Faculdade de Filosofia, sob orientação de Gilda de Mello e Souza. "[...] Estudo demais preparando o doutoramento para daqui a três anos - depois, liberdade. E poesia até o fim”, escreveu a Drummond $^{56}$. Pensou, a princípio, em "pesquisar a contribuição da psicanálise à estética - examinar o conceito de sublimação e verificar [isso] na obra de um artista. (Imagine que me sugeriram você, mas eu jamais seria chata [com] um amigo querido). [...]" Pensou então em Cecília, depois em Cabral. Até decidir-se pela obra de um aparentado

54 XAVIER, Ismail. Depoimento em homenagem da ECA nos vinte anos da morte da escritora. In: Simpósios em Comunicações e Artes. n. 7. São Paulo: ECA-USP, 1990. p. 30-33.

55 Dirigido por Eduardo Leone, depois professor da ECA, já falecido.

56 GARAUDE, Lupe Cotrim. Cartão de boas festas, dezembro de 1967. 
deste, o francês Francis Ponge ${ }^{57}$, apóstolo da autonomia da palavra poética, o poeta do existencialismo, segundo Sartre.

Um pouco dessa pesquisa, é possível entrever na coletânea póstuma, Poemas ao outro, que Drummond, na sua morte, chamaria de o seu "mais sério livro" 58 . Livro, afinal, cujos originais foram revistos pelo próprio poeta, a pedido de Lupe. Em abril de 1969, já instaurado o Ato5, seu marido, o filósofo José Arthur Giannotti, aos 39 anos, foi um dos professores da USP aposentados compulsoriamente pelo regime militar. Aflita, Lupe escrevia a Drummond, relatando o ébranlement que isto acarretava ao casal: “[...] não podendo ensinar, só lhe resta partir. O que faremos no fim do ano, provavelmente para a França. Eu ainda não fui 'aposentada' - pedirei afastamento da universidade [...]”. E lamentava, como poeta, precisar distanciar-se da língua portuguesa ${ }^{59}$. Na dúvida se deveria publicar de imediato seu novo livro, pronto, ou deixá-lo ainda “amadurecer", pede uma avaliação sobre os originais ao amigo. E se dispunha a ir ao Rio para ouvir, de viva voz, sua opinião. $O$ acerto deve terse dado por telefone ou outro meio, pois não há resposta de Drummond. Mas eles se encontraram no Rio, conforme sua última carta ao poeta: “[...] Não falei mais frente ao Nejar, pois não quis que ele visse que você aceitou de mim esse tipo de chateação de ler originais. [...]"60

Os planos de mudar-se com a família para a França se desfizeram. A viagem de Lupe foi outra. A um imaginário homem do povo, João, símbolo dos milhões de excluídos do banquete capitalista, ela dirige os Poemas ao outro. No qual, a contrapelo de todas as adversidades, canta ainda a vida e a alegria:

$[\ldots]$

Se o gesto é escrito

e perduras analfabeto, se o pão é farto

e teu estômago descalço

se alguns vão à lua

no esplendor da técnica

e prossegue a miséria em sua chaga satélite, alegria, João.

Por um outro dia

57 Informação prestada por José Arthur Giannotti em 30 de outubro de 2007.

58 ANDRADE, Carlos Drummond de. Lupe, rápida. In Jornal do Brasil, 28 fev. 1970.

59 GARAUDE, Lupe Cotrim. Carta de 29 maio 1969.

60 Idem. Carta de 10 set. 1969. A referência é a Carlos Nejar, outro expoente da "geração $60 "$ ". 
necessitamos fazer parte

do que nele principia. [...]

Alegria pela manhã

que contra hoje vai chegar

sub-versiva, sub-vertida

sub-metida.

Alegria de nós, em nosso intento:

alegria como é viva

uma pessoa viva. ${ }^{61}$

Publicado sete meses depois de sua morte, o último e premiado livro traz prefácio de André Carneiro, sintetizando a meteórica passagem da poeta pela cena literária e cultural brasileira:

[...] Lupe Cotrim Garaude foi uma escritora verdadeira e uma intelectual completa. Uma escritora profissional, diríamos, no sentido da dedicação, da seriedade, do estudo, que ela dedicava à sua carreira, com a constância e a modéstia das verdadeiras vocações. [...] Sua personalidade forte, se impondo sem favores [...], procurava emprestar um racionalismo masculino, uma quase frieza, que contrastava com a sua beleza física. [...] Infelizmente sua carreira foi interrompida exatamente quando acumulara todos os meios para se realizar plenamente como poeta e escritor. Além da sua obra, patrimônio que vale para todos, os seus amigos guardarão dela a sua personalidade marcante, a sua beleza, que ela parecia querer disfarçar, quase tímida, debaixo da sua erudição. [...] Sua obra fica, inclusive para nos consolar, com a dura verdade poética destes versos: "Em cada manhã / reinventar descobertas. / Os mortos às costas / e o amor sem recesso" ${ }^{62}$

No Rio, Carlos Drummond reservou uma de suas crônicas à despedida de Lupe, republicando aquela "bela entrevista" feita em 1958 - tempo em que um dos sonhos dos dois amigos poetas, o de um país menos injusto, ainda parecia ser uma possibilidade para amanhã.

Recebido em 11 de junho de 2008

Aprovado em 15 de novembro de 2008

61 Idem. João, fragmentos. In: Poemas ao outro. São Paulo: Comissão Estadual de Cultura, 1970. p. 38-41.

62 Idem, Ibidem, p. 5-8. 